\title{
Temperature analysis for Earth air heat exchanger
}

\author{
Baljit Singh $^{\# 1}$, Arun Kumar Asati ${ }^{* 2}$ Rakesh Kumar $^{\# 3}$ \\ ${ }^{\# 1}$ Ph.D Research Scholar, Department of Mechanical Engineering IKGPTU Kapurthala, Punjab, India. \\ \#3 IET Bhaddal, Ropar Punjab, India \\ ${ }^{1}$ baljitbhullar22@gmail.com \\ 33kthakur99@rediffmail.com \\ *Department of Mechnaical Engineering, SBSSTC, Ferozepur, Punjab, India. \\ SBSSTC, Ferozepur, Punjab, India. \\ 2 arunkasati@yahoo.com
}

\begin{abstract}
Now a days save electricity is major concern for societal needs. Various Conventional methods used for to save environment. To make comfort environment many techniques used like thermal comfort. The use of geothermal energy is the best way to make environment healthy for mankind and to reduce the demand of electricity which is increasing day by day. The Earth Air Heat Exchanger system is a best passive technology to the use of geothermal energy. The investigation shows the major temperature drop of $8.9^{\circ} \mathrm{C}$ corresponding to inlet temperature $\left(T_{i n}\right) 41.9^{\circ} \mathrm{C}$ on date 31 March 2017 , minor drop of 1.1 ${ }^{\circ} \mathrm{C}$ corresponding to inlet temperature $\left(T_{\text {in }}\right) 26.2{ }^{\circ} \mathrm{C}$ on date 5 April 2017. In this research paper efforts will be made to study the accomplishment of low cost cooling system for hot-dry climate.
\end{abstract}

Keyword - Geothermal energy, Passive, climate.

\section{INTRODUCTION}

This type of heat exchanger is good for making environment comfort for human beings. It uses the undisturbed temperature of earth for cooling the room. The undisturbed temperature remains constant. It consists of group of buried pipes under the earth through which the air passed through a fan or blower. The material of the pipe may be Poly Vinyl Chloride (PVC), Mild Steel and Concrete. The design parameters that impact the evaluation of this system are: pipe depth, pipe length, pipe diameter, air velocity, air flow rate, pipe material, pipe arrangement [1]. In this paper the Earth Air Heat Exchanger (EAHE) system is studied for hot-dry climate. Airconditioning systems is the largest energy consumer that is the biggest challenge which arisesnow days. This problem can be overcome by the use of ground coupled heat exchanger in air conditioning system [2]. It suitably meets heating and cooling energyloads of a building. Its performance is based uponthe seasonally varying inlet temperature, and out lettemperature which further depends on the groundtemperature [3].

This heat exchanger built by burying in the ground at a particular depth so that the required cooling and heating can be achieved from system. This air is often outside air for ventilation, but also useful for partially or totally managing thermal loads of construction [4]. In present research study efforts will be made to save electricity by proper set-up of EAHE in spite of using other conventional systems in houses.

The climatic conditions and parameters used strongly affect this system. The modifications of the system depend upon the variation in the parameters used [5]. The set up is free from any dust particles enter into the pipe of heat exchanger which block the passage of air through the pipe.

A large amount of the primary energy is consumed by space heating and cooling in buildings/houses. The requirement of huge renewable energy in the building sector and industrial establishments is the demand for sustainable energy and environments. Geothermal energy is one of the renewable energy sources that we utilised for supplying air at low expense of energy and with a low impact on the environment [6]. The utilizing styles and exploring methods are various, geothermal electricity, ground source heat pump, earth to air heat exchanger (EAHE), etc. are the main application measures. Among them, an EAHE has the advantages of simple system, easy implementation and low operation cost [7].

The use of earth as a component of energy system can be accomplished through three primary methods: direct, indirect and isolated. In direct system, the building is in contact with the earth through the pipes and fresh air form the environment maintains the comfort temperature. In the indirect system, the building interior is cooled by a low cost cooling system or by an earth air tunnel heat exchanger. The isolated system uses the geothermal temperature of earth to enhance the effectiveness of a heat pump by moderating temperatures [8].

The ground temperatures at several depths can be measured, the overall heat transfer coefficient (overall HTC) can be determined; the heat exchange rate quantified. The HGHE consists of $50 \mathrm{~m}$ of length buried at $1 \mathrm{~m}$ of depth. The energy and exergy analysis of horizontal ground heat exchanger (HGHE) for hot climatic conditions can be determined [9]. The objective of this study is to found a low cost cooling system with the help of this passive method of cooling for ho-dry climate. 


\section{EXPERIMENTAL SET-UP AND INSTRUMENTATIONS}

It consists of burial concrete pipe of diameter $0.224 \mathrm{~m}$ and is buried in the soil at a distance of $1.5 \mathrm{~m}$. The one end of buried pipe is open to the fields and other end is in the room for testing. A blower is connected to the open end of pipes which deliever air to the room for study. The temperature will be measured with the help RTDs of $0.5^{\circ} \mathrm{C}$ accuracy and least count $0.1^{\circ} \mathrm{C}$, range $0-100^{\circ} \mathrm{C}$. The RTDs are connected at two different points. One at the inlet to the pipe and other is at the outlet of the pipe. The arrangement of different instruments used for the investigation of the complete system shown in fig 1.

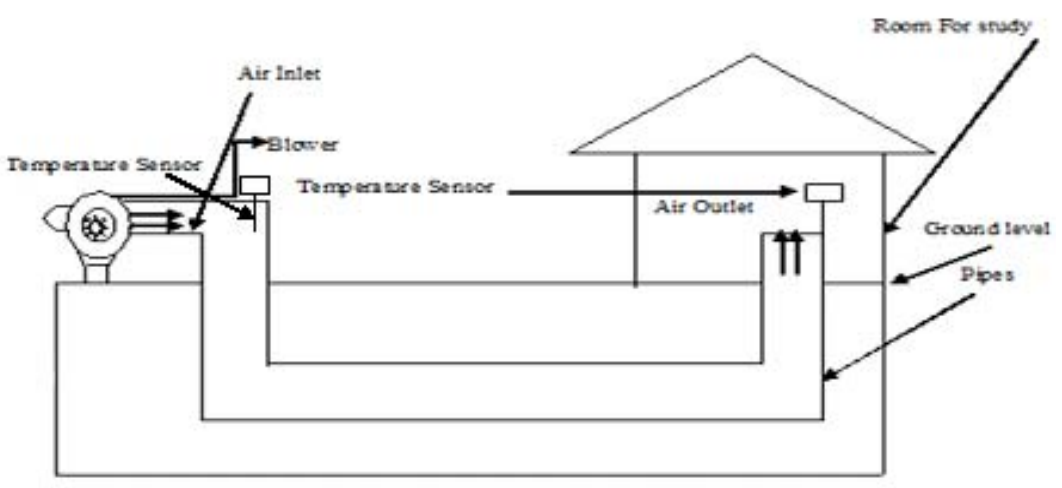

Fig 1.Schematic Diagram of the experimental set-up

\section{METHODOLOGY}

The EAHE system is switch on and air is flows through the pipes from inlet to outlet from time 7.30 am to 4.00 pm on eight days i.e 29 March 2017 to 5 April 2017. The temperature reading is noted for every half hour. The dry bulb temperature is noted at two points. The buried pipes and temperature indicators are shown in Fig 2.

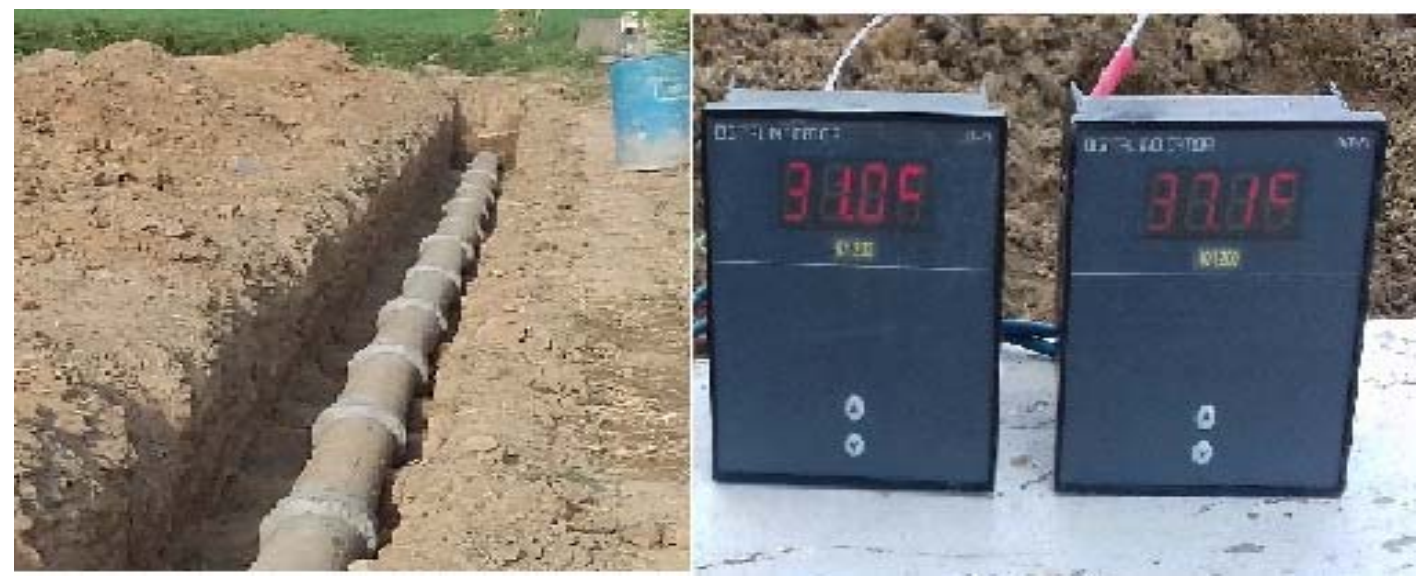

Fig 2.the buried pipes and temperature indicator used for study.

\section{RESULTS \& DisCuSSIONS}

\section{A. EFFECT OF TEMPERATURE}

In the study of earth air heat exchanger temperature difference between the inlet temperature $\left(T_{\text {in }}\right)$ and outlet temperature $\left(\mathrm{T}_{\text {out }}\right)$ plays an important role. The temperature drop of $2.1^{\circ} \mathrm{C}$ is observed at 8.00 am which is caused by minor difference in inlet temperature and soil temperature. The inlet temperature line rapidly goes on increasing after 9.00 am due to rise in $\mathrm{T}_{\text {in }}$ temperature from value $30.6{ }^{\circ} \mathrm{C}$ to $32.3^{\circ} \mathrm{C}$. The drop of only $0.2{ }^{\circ} \mathrm{C}$ is available from time $11.00 \mathrm{am}$ to $11.30 \mathrm{pm}$ which is because of less heat transfer between air and soil at that time. The major drop of temperature is $7.4^{\circ} \mathrm{C}$ experienced after $1.30 \mathrm{pm}$ because of excess rise in $\mathrm{T}_{\text {in }}$ to value $36.4^{\circ} \mathrm{C}$. The maximum temperature drop is available because of maximum difference in inlet temperature and soil temperature which increasing the rate of heat transfers from air in the pipe and the soil. The lines of temperatures $\mathrm{T}_{\text {in }}$ and $\mathrm{T}_{\text {out }}$ come closer and closer after $3.00 \mathrm{pm}$ and the fall is equal to $5.4{ }^{\circ} \mathrm{C}$ due to decrease in inlet temperature and undisturbed temperature of earth. The undisturbed temperature of the earth is that temperature which remains almost constant throughout the year. 


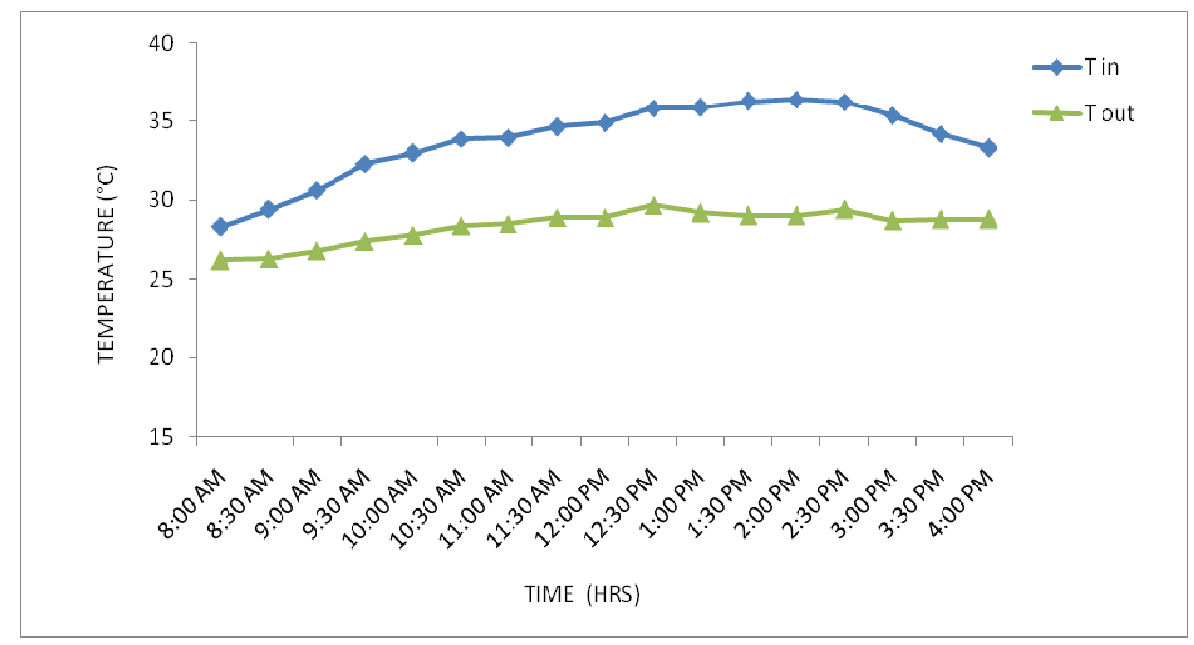

Fig 3.Variation of time vs. temperature on 29 March 2017

The drop of temperature is low after 8.30 am caused by hot waves passing near blower during morning time. The fall of temperature is constant and equal to $7.4^{\circ} \mathrm{C}$ from time $1.00 \mathrm{pm}$ to $1.30 \mathrm{pm}$ this is due to same $\mathrm{T}_{\text {in }}$ temperature $36.3^{\circ} \mathrm{C}$ at that time. As we know the maximum outdoor temperature at the time of 2:00 pm is 36.6 ${ }^{\circ} \mathrm{C}$ of the summer day. Therefore from the figure 4 it is found that the maximum drop of temperature at the time of 2:00 pm is $8.1^{\circ} \mathrm{C}$. Therefore this study is completely validating the results obtained from the experiment the maximum heat transfer depends upon the difference of two temperatures. The trends of two lines $T_{\text {in }}$ and $T_{\text {out }}$ shows that difference is reducing after $2.00 \mathrm{pm}$ as the environment temperature goes on decreasing when sun is sets in evening. Also difference in temperature observed at the time of $4.00 \mathrm{pm}$ is $6.5^{\circ} \mathrm{C}$.

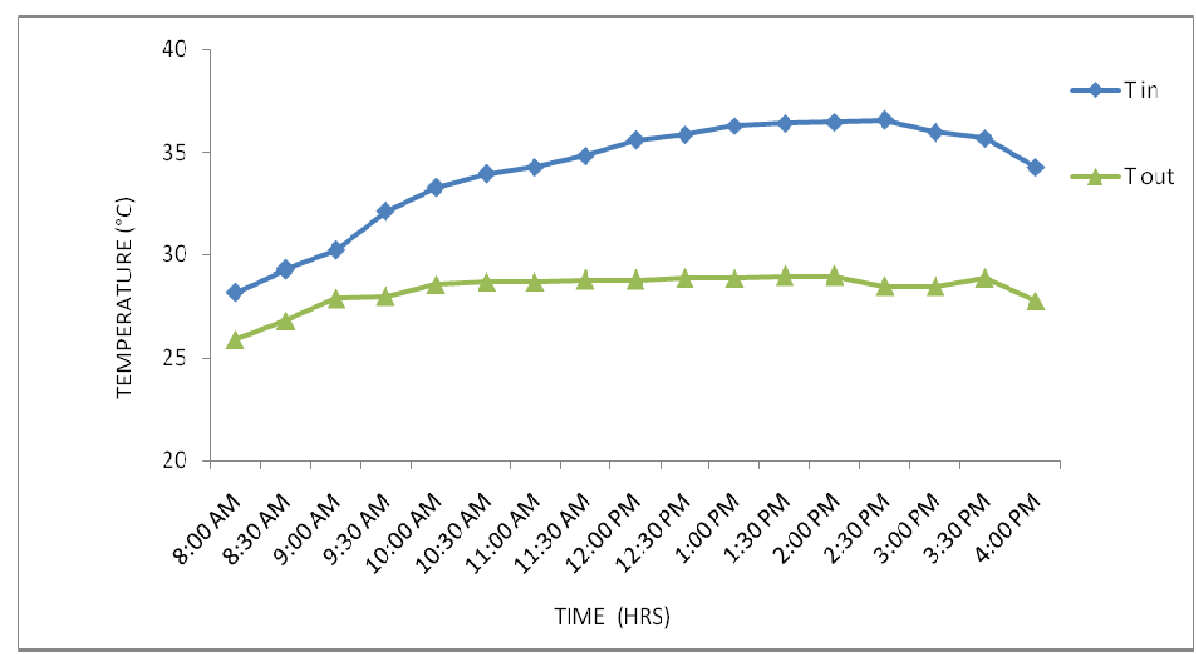

Fig 4.Variation of time vs. temperature on 30 March 2017

The inlet temperature line after 10.30 suddenly bends downwards which is because of worse climatic conditions at that time and fall is equal to $5.5^{\circ} \mathrm{C}$. The performance of earth air heat exchanger is greatly affected by the outdoor climatic conditions. The $\mathrm{T}_{\text {in }}$ curve of temperature extends upwards after $12.00 \mathrm{pm}$ because of rise in temperature of environment. Maximum temperature difference on this day at the time of $2.00 \mathrm{pm}$ is $8.9^{\circ} \mathrm{C}$ and Minimum temperature difference at the time $8.00 \mathrm{am}$ is $2.5^{\circ} \mathrm{C}$. The heat transfer at the interface between soil and the pipe surface is calculated using the general heat transfer equation, assuming that there is no contact resistance. 


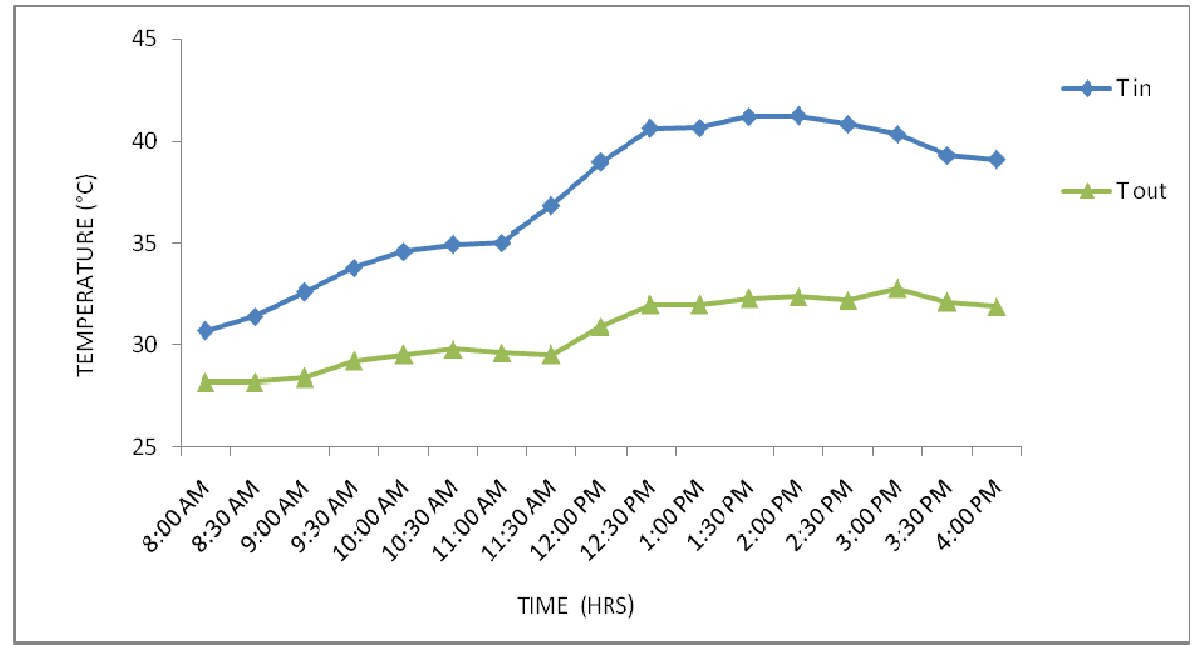

Fig 5.Variation of time vs. temperature on 31 March 2017

The variation in two curves of $T_{\text {in }}$ and $T_{\text {out }}$ on that day shows abrupt changes caused by rain in some areas of Ferozepur. Therefore the inlet temperature varies and corresponding outlet temperature varies. The study of EAHE reveals that the performance of system can be improved by making system completely dust free. Due to worse environmental conditions and passing away of clouds the temperature after 10.30 am changes abruptly and drop of temperature varies from $5.6^{\circ} \mathrm{C}$ to $6.9^{\circ} \mathrm{C}$ from $11.00 \mathrm{am}$ to $12.00 \mathrm{pm}$. The maximum temperature difference after the time of $1.30 \mathrm{pm}$ is $8.2^{\circ} \mathrm{C}$ and minimum temperature difference at the time $8.00 \mathrm{am}$ is $2.9{ }^{\circ} \mathrm{C}$ as shown in Figure 6. The temperatures of soil, air and heat exchanger and the heat transfer rate also vary along the air flow direction (inside the heat exchanger).

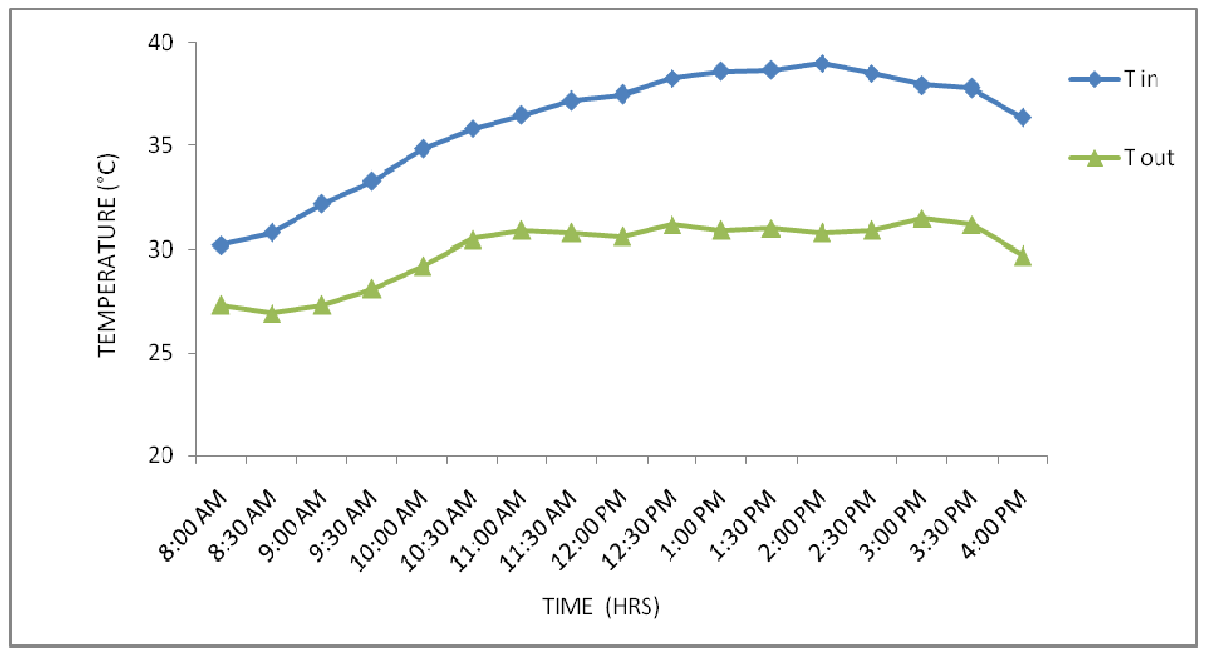

Fig 6.Variation of time vs. temperature on 1 April 2017

The temperature observations on 2 April 2017 are shown in figure 7. The minimum temperature difference $\left(\mathrm{T}_{\mathrm{in}}-\mathrm{T}_{\text {out }}\right)$ of $2.2{ }^{\circ} \mathrm{C}$ is observed because of morning time at the inlet and outlet of the pipe at time 8.00 am as shown figure 7 . The difference of inlet temperature $\left(T_{\text {in }}\right)$ and temperature of tested room $\left(\mathrm{T}_{\text {out }}\right)$ continuously shows increasing trends with increase in environment temperature. The fall of temperature of 6.0 ${ }^{\circ} \mathrm{C}$ is available at time 10.30 am because of inlet temperature is reaches to $35.9{ }^{\circ} \mathrm{C}$ at that time. The maximum drop of the day is available at $1.30 \mathrm{pm}$ is $8.4^{\circ} \mathrm{C}$ corresponding to maximum environment temperature of $39.3^{\circ} \mathrm{C}$ at that time. This maximum fall of temperature observed due to excess heat transfer between the air and soil. The inlet temperature $\left(\mathrm{T}_{\text {in }}\right)$ of $3.00 \mathrm{pm}$ shows variation in downward direction with temperature drop of equal to $6.7^{\circ} \mathrm{C}$ which occurs because of decrease in inlet temperature to value $37.1^{\circ} \mathrm{C}$ and therefore less heat transfer. The drop of $5.5^{\circ} \mathrm{C}$ is observed at the time of $4.00 \mathrm{pm}$. 


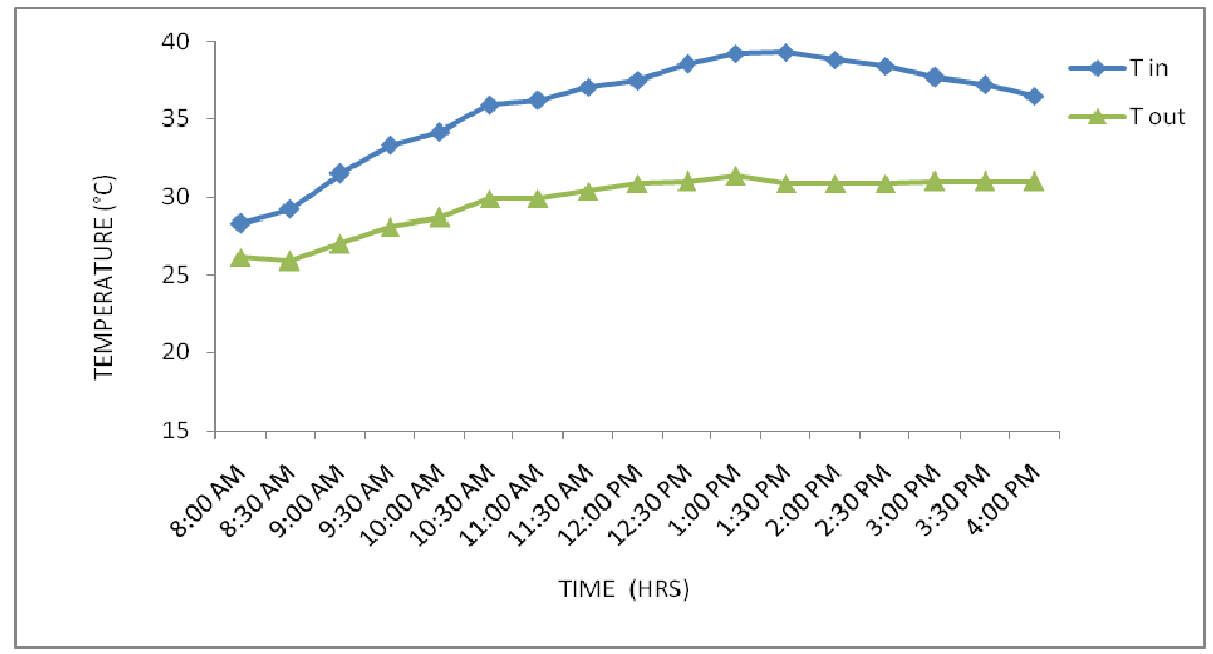

Fig 7.Variation of time vs. temperature on 2 April 2017

The time vs. temperature plots on date 3 April 2017 are shown in fig 8. The curve of inlet temperature is suddenly deflected upwards at 9.00 am due to rise in inlet temperature $\left(\mathrm{T}_{\text {in }}\right)$ is $33 .{ }^{\circ} \mathrm{C}$ and corresponding outlet temperature $\left(\mathrm{T}_{\text {out }}\right)$ is $29.1^{\circ} \mathrm{C}$. The fall is $1.7^{\circ} \mathrm{C}$ more than 2 April 2017 as the environment temperature is $33.3^{\circ} \mathrm{C}$ instead of $31.5^{\circ} \mathrm{C}$ at $9.00 \mathrm{am}$. The temperature fall of $7.5^{\circ} \mathrm{C}$ is observed after time of $12.00 \mathrm{pm}$. The curve is bending to downward direction at time $1.30 \mathrm{pm}$ is because of cool air prevailing around the blower. The maximum drop of the day available at $2.30 \mathrm{pm}$ is $8.5^{\circ} \mathrm{C}$ and increases because of use of concrete pipes for construction of earth air heat exchanger as other researchers used the PVC pipes whose conductivity is less than concrete. The inlet temperature reaches to $40.3^{\circ} \mathrm{C}$ at $3.00 \mathrm{pm}$ and corresponding fall observed is $8.1^{\circ} \mathrm{C}$. The fall is increasing continuously as the day reaches to peak heating of the day. The increase in heat transfer rate as the difference in inlet temperature (hot) and soil temperature (cold) is increases. Fall of temperature decreases and becomes almost constant to value $7.5^{\circ} \mathrm{C}$ to $7.0^{\circ} \mathrm{C}$ from time of $3.30 \mathrm{pm}$ to $4.00 \mathrm{pm}$.

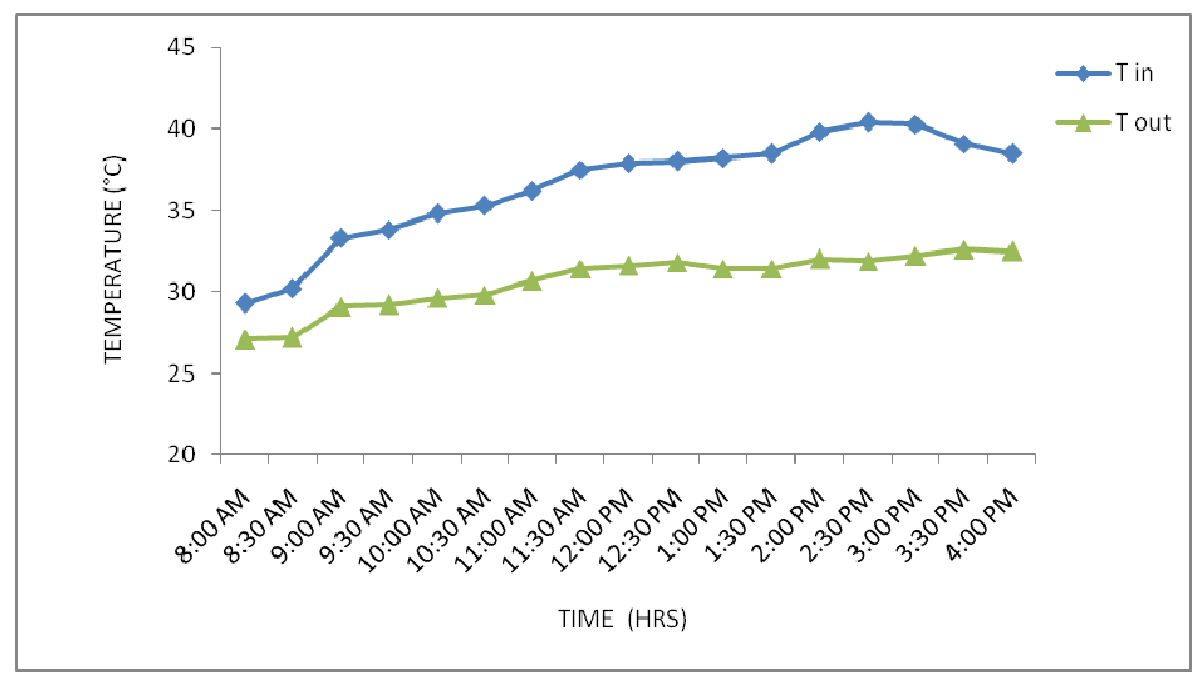

Fig 8.Variation of time vs. temperature on 3 April 2017

Figure 9 shows the temperature variations on 4 April 2017. The inlet temperature $\left(\mathrm{T}_{\text {in }}\right)$ on this day increasing in continue manner. The minimum temperature drop of $2.3^{\circ} \mathrm{C}$ is as usually observed at time $8.00 \mathrm{am}$. This is due morning time and difference in soil temperature and environment temperature. A small fall of $0.3^{\circ} \mathrm{C}$ is observed from $9.00 \mathrm{am}$ to $9.30 \mathrm{am}$ is because of small rise in environment temperature of $0.9^{\circ} \mathrm{C}$. The drop of temperature is changes from $4.4{ }^{\circ} \mathrm{C}$ to $5.4{ }^{\circ} \mathrm{C}$ from time $10.00 \mathrm{am}$ to $10.30 \mathrm{am}$ is due to same condition of air and less change in environment temperature. The reading of two temperatures $\mathrm{T}_{\text {in }}$ and $\mathrm{T}_{\text {out }}$ shows considerable change in the inlet and outlet values of temperature at the time of $2.00 \mathrm{pm}$ is $8.0{ }^{\circ} \mathrm{C}$ as the maximum environment temperature of the day is $37.2^{\circ} \mathrm{C}$ at $2.00 \mathrm{pm}$. The environment conditions affect the EAHE system considerably. 


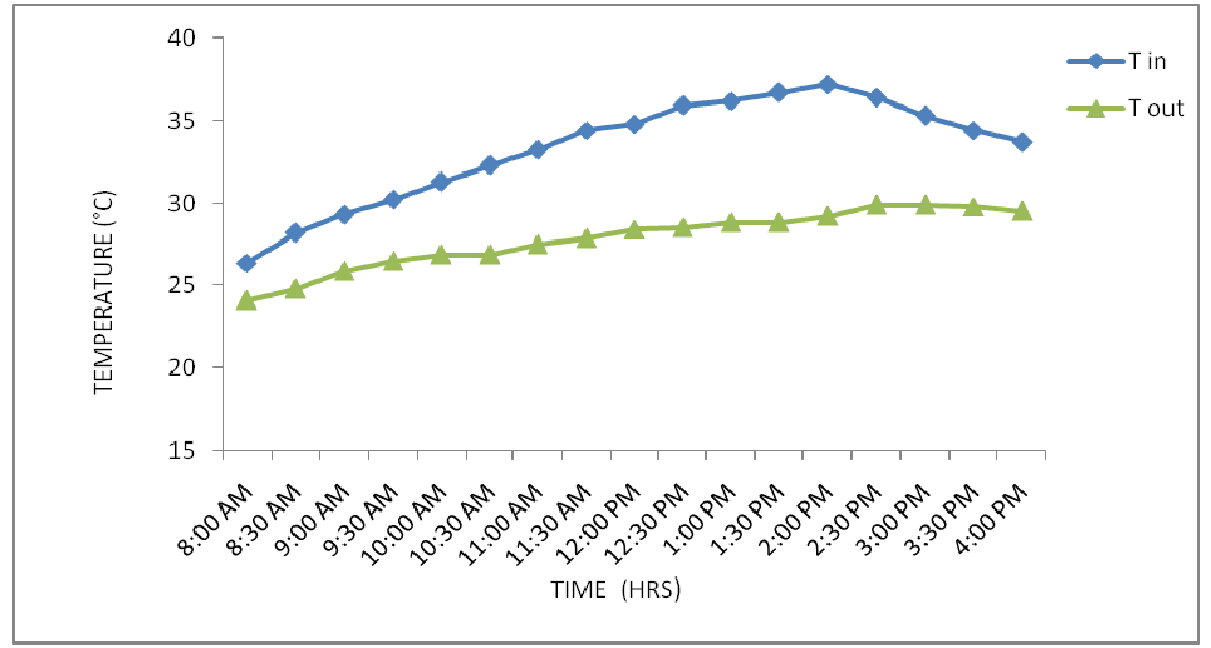

Fig 9.Variation of time vs. temperature on 4 April 2017

A figure 10 shows at 8.00 am the inlet temperature $\left(T_{\text {in }}\right)$ is $26.2{ }^{\circ} \mathrm{C}$ at this temperature the minimum fall available is $1.1^{\circ} \mathrm{C}$. The drop temperature is $1.9^{\circ} \mathrm{C}$ at the time of $8.30 \mathrm{am}$. The temperature drop is slowly increasing in morning hours, drop is rises to maximum value in peak hours and drop decreases as the environment temperature decreases from peak hours of the day. Temperature fall of only $0.1^{\circ} \mathrm{C}$ observed from time $12.30 \mathrm{pm}$ to $1.00 \mathrm{pm}$ which caused by worse climatic conditions. The maximum value of $\mathrm{T}_{\text {in }}$ at $2.00 \mathrm{pm}$ is $30.4^{\circ} \mathrm{C}$ and corresponding maximum fall observed is $5.7^{\circ} \mathrm{C}$ due to the air crashes around constantly inside the pipes maximizing the air to wall contact for complete heat exchange and, in the summer, removal of excess air moisture through condensation. The 5 April 2017 is coolest day as compared to other days because the inlet temperature rises to $30.4^{\circ} \mathrm{C}$ only. The drop decreases as the environment temperature decreases after the time $2.00 \mathrm{pm}$.

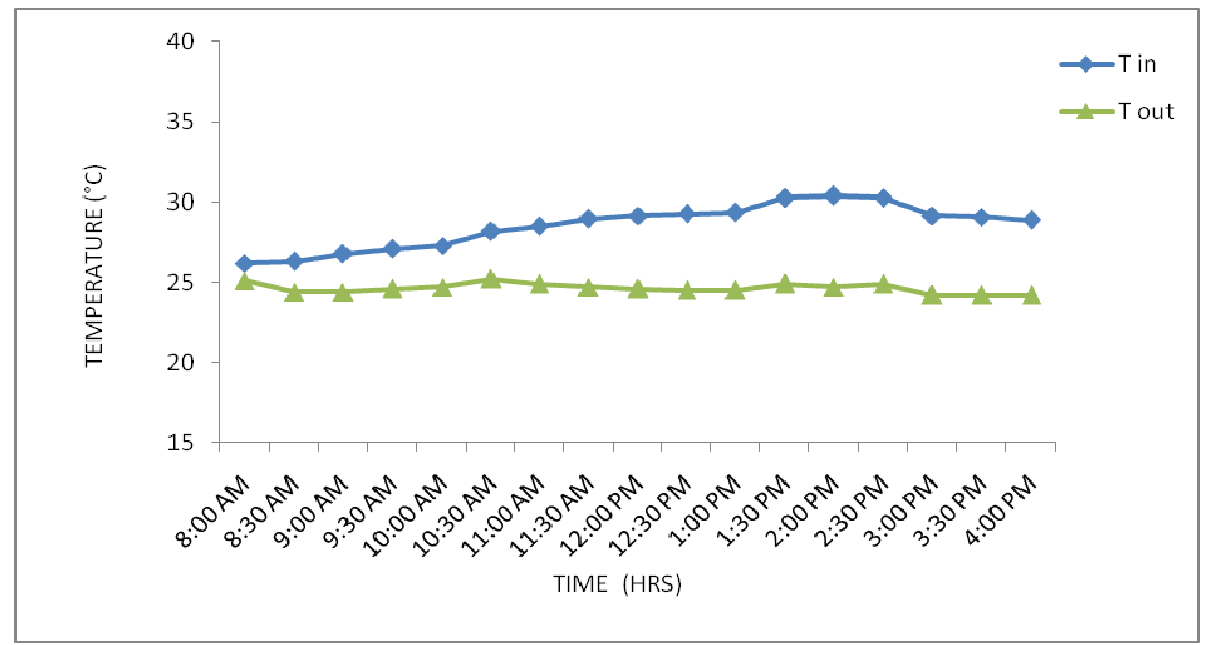

Fig 10.Variation of time vs. temperature on 5 April 2017

The average temperature fall vs. no. of days shows in figure 11 from date 29 March to 5 April 2017. The plots of average fall vs. no. of days provide more clear and concise picture of temperature variations. The drop on 29 March 2017 is equal to is $5.5^{\circ} \mathrm{C}$ which is because of average $\mathrm{T}_{\text {in }}$ temperature of $33.8^{\circ} \mathrm{C}$ air and average $\mathrm{T}_{\text {out }}$ temperature of $27.3^{\circ} \mathrm{C}$. The fall of $5.7^{\circ} \mathrm{C}$ is observed on $2^{\text {nd }}$ day caused by velocity of air $2.5 \mathrm{~m} / \mathrm{s}$ on that day. The average inlet temperature curve extends upward after $3^{\text {rd }}$ day which gives the indication of warmer day from all other days. The amplitude of average inlet temperature curve is maximum this is because of maximum average $\mathrm{T}_{\text {in }}$ of $37.2^{\circ} \mathrm{C}$ on 31 march 2017 and corresponding maximum drop of temperature $6.6^{\circ} \mathrm{C}$ on that day. The fall of temperature decreases by $0.4{ }^{\circ} \mathrm{C}$ due to decrease in average $\mathrm{T}_{\text {in }}$ temperature from $37.2^{\circ} \mathrm{C}$ to $36.1{ }^{\circ} \mathrm{C}$ on 1 April 2017. On 2 April 2017 the average inlet temperature is $35.8^{\circ} \mathrm{C}$ and average outlet temperature is 29.7 ${ }^{\circ} \mathrm{C}$ is $6.1{ }^{\circ} \mathrm{C}$. The average inlet temperature $36.5^{\circ} \mathrm{C}$ which is maximum than other days and average outlet temperature is $30.0^{\circ} \mathrm{C}$ corresponding maximum fall than other days is $6.5^{\circ} \mathrm{C}$ which because of maximum rate of heat transfer between inlet (hot) temperature and soil (cold) temperature. The drop of temperature on $7^{\text {th }}$ day is less as compared to day 2 due to fewer rises in average inlet temperature. The drop of temperature at that day is $5.4^{\circ} \mathrm{C}$. The lines of plots bend in downward direction on day 8 shows that it is cooler than other days and 
corresponding drop in temperature is less and equal to $3.9^{\circ} \mathrm{C}$ as shown in figure 11 . It can be observed that the changes in the temperatures and heat transfer rate along the pipe are not linear.

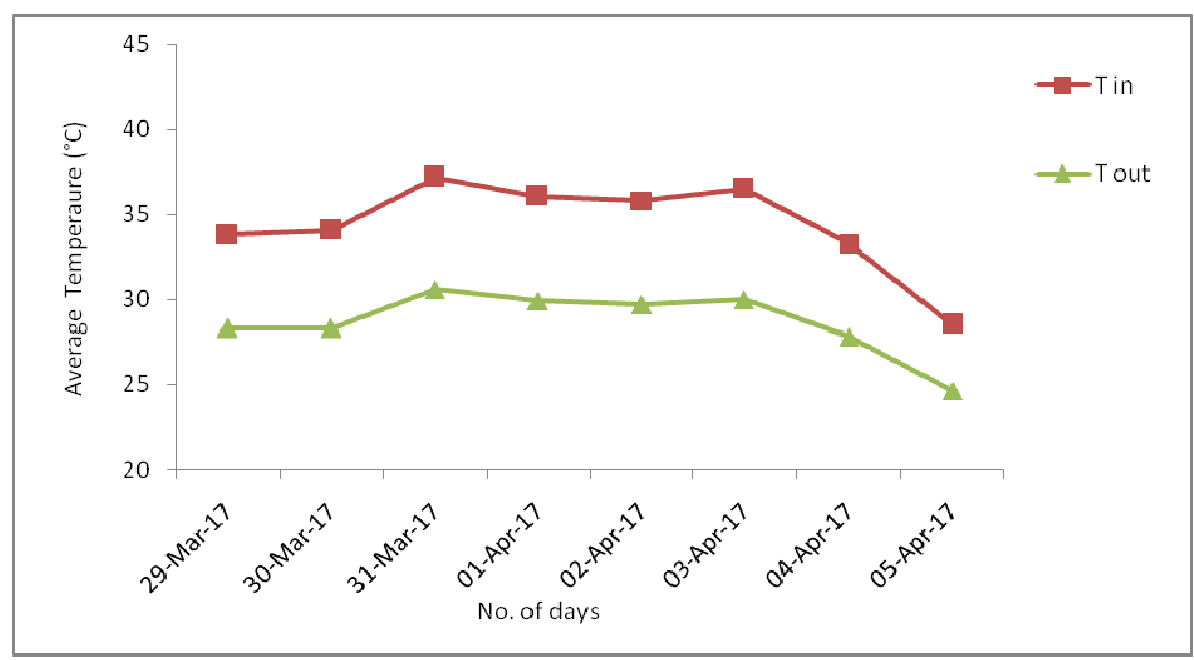

Fig 11. Average temperature fall vs. No. of days.

\section{CONCLUSION}

The findings from Earth air heat exchanger brings us that technology of varying temperature with the soil temperature found many benefits like energy saving, money is saving and environment saving. These benefits may help us lot in future in the field of renewable energy resources which is peak demand of the society. The loss of energy can be minimized with the help such type of systems. The use of EAHE is very limited in the state of Punjab and therefore the Punjab can become energy crisis state in few years; if renewable energy resources not implemented at state level. The investigation shows the major temperature drop of $8.9{ }^{\circ} \mathrm{C}$ corresponding to inlet temperature $\left(\mathrm{T}_{\text {in }}\right) 41.9^{\circ} \mathrm{C}$ on date 31 March 2017 , minor drop of $1.1^{\circ} \mathrm{C}$ corresponding to inlet temperature $\left(\mathrm{T}_{\text {in }}\right) 26.2^{\circ} \mathrm{C}$ on date 5 April 2017.

\section{ACKNOWLEDGMENT}

Authors are thankful to the IKG Punjab Technical University, Kapurthala for giving us this opportunity to go for the research work. The investigations of Earth Air Heat Exchanger may not be fulfilling with the kind help of Dr ArunKumar Asati, Associate Professor, Shaheed Bhagat Singh State Technical Campus, Ferozepur. I also thank Dr. Rakesh Kumar, Associate professor and Head of Mechanical Engineering Department at IET, Bhaddal, Roparwho helped me a lot at every step of my research.

\section{REFERENCES}

[1] Bhoge Dipak \&Nadaf Sameer (2016), "A Review on performance enhancement of Air conditioner Using Earth Air Tunnel heat Exchnager ” IJLTET, Volume 6, Issue 4, March 2016.

[2] Naik B. Devaraj\& MundlaSubba Reddy (2016), "Research Review on Earth Pipe Air Conditioning System” ISSN: 2395-0072, DEC 2016 IRJET, Volume 3, Issue 12.

[3] Manjul Ravi Ranjan\&Bartaria V.N (2016), "Earth Air Heat Exchanger Performance in Summer Cooling For Various Supply Air Conditions - A Review” MAY 2016 IJETT, Volume 35, Issue 8.

[4] Tyagi Vishal kumar (2016), "Experimental Performance Analysis of Earth Air Heat Exchanger” Journal of Material Science and Mechanical Engineering (JMSME) p-ISSN: 2393-9095; e-ISSN: 2393-9109; Volume 2, Issue 14; October-December, 2015, pp 40-44.

[5] Patel Rakesh D and Ramana P. V. (2016), "Experimental Performance of Buried Tube Heat Exchanger Validated by Simulation Performance in Heating Climate Condition” ISSN: 2455-3689, IJRTEM, Volume 1 Issue 1, Feb. 2016, pp 01-05.

[6] Niu Fuxin, Yu Yuebin, Yu Daihong, Li Haorong (2015), "Heat and mass transfer performance analysis and cooling capacity prediction of earth to air heat exchanger" Applied Energy 137 (2015) 211-221.

[7] Lund JW, Freeston DH, Boyd TL (2005) “Direct application of geothermal energy” Geothermics 2005; 34(6):691-727.

[8] Kaur Jagjeet, Singh Prem, Kaur Harminder (2015), "A Review on the Experimental and Analytical Analysis of Earth Air Tunnel Heat Exchanger System” Environmental Sustainability: Concepts, Principles, Evidences and Innovations - ISBN: 978-93-83083-75-6.

[9] Naili Nabiha, Hazami Majdi, Kooli Sami, Farhat Abdelhamid (2015), "Energy and exergy analysis of horizontal ground heat exchanger forhot climatic condition of northern Tunisia” ISSN: 2455-3689, IJRTEM, Volume 1 Issue 1, Feb. 2016, pp 01-05. 

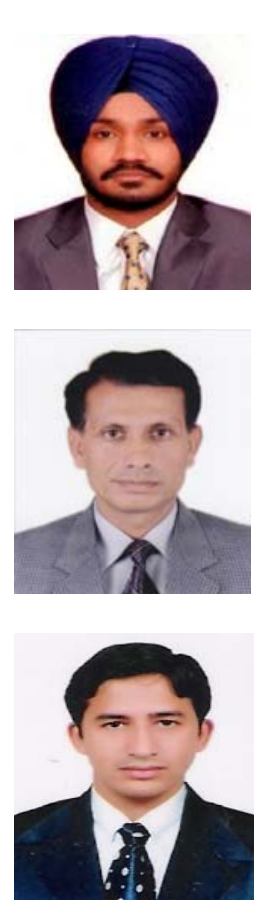

\section{AUTHOR PROFILE}

Baljit Singh is Ph.D Research Scholar, Department of Mechanical Engineering, IKGPTU Kapurthala, Punjab, India. He is working in the department of Mechanical Engineering in SBSSTC, Ferozepur, Punjab,India. He has 8 years of teaching experience. He has specialisation in Material, Coating and Thermal Engineering.

Dr. Arun Kumar Asati is working as Associate Professor at SBSSTC, Ferozepur, Punjab,India. He completed his Ph.D from IIT, Delhi. He has 30 years experience in the field of teaching. He has specialization in thermal engineering. He is very hard working. He has published many research publications in international journals and international conferences.His areas of interests are Heat Transfer, Refrigeration and Air Conditioning, Thermodynamics and Desiccant Cooling.

Dr. Rakesh Kumar is working as Associate Professor and Head of Mechanical Engineering Departmentat IET, Bhaddal, Ropar, Punjab. He completed his Ph.D from IKGPTU, Kapurthala in 2016. He has more than 16 year teaching experience in the field of Mechanical Engineering. His areas of interests are Heat Transfer, Refrigeration and Air Conditioning, Micro tubes and Thermal Engineering. He has published many research papers in international journals and conferences. 